\title{
NIH's way of setting priorities endorsed
}

[WASHINGTON] An expert panel charged with deciding whether the US National Institutes of Health $(\mathrm{NIH})$ should change the way it sets research priorities heard general praise for the agency's methods last week, and seemed averse to recommending dramatic changes when it reports in July.

Last week's meeting marked the launch of a study by the Institute of Medicine (IOM) into whether the way in which the NIH sets priorities for distributing its $\$ 13.65$ billion - and growing - budget should be changed, honed or left alone.

Judging from the tenor of the meeting, the committee is more likely to recommend incremental reforms than a dramatic overhaul. "We're not dealing with something that's broken," says Leon Rosenberg, a professor of molecular biology at Princeton University who chairs the 20-member panel. "We're looking for ways to make a good thing better."

NIH directors who addressed the panel suggested one way that might be achieved: by Congress ceasing to burden the agency with legal requirements to spend money on particular diseases. Such constraints "deform" science, they said.

The $\$ 338,000$ IOM study was ordered last year by Congress. It was prompted by the perennial tug of war between the scientific community, which prefers a free hand in deciding how it spends research dollars, and advocates for dozens of diseases, who argue that their causes are underfunded by NIH in a process that excludes the public.

Both sides have support in Congress. Last

week Representative John Porter (Republican, Illinois) took Donna Shalala, the secretary of the Department of Health and Human Services, to task for what he alleged was White House meddling in NIH priority-setting. President Bill Clinton "is setting one disease against another" by seeking in his 1999 budget a five-year, 65 per cent increase in cancer research spending at the NIH, said Porter.

Porter, who chairs the House of Representatives appropriations subcommittee that funds the NIH, said Clinton had opened "a Pandora's box" with the proposal. Shalala defended the proposed increase as "not inappropriate" because, during the same five-year period, overall NIH spending would increase by 48 per cent. She said "cancer is on the cusp of a series of major breakthroughs and this additional investment will make a major difference in the quality of life".

The issue is also coming to a head this year because of the concerns of Senator Bill Frist (Republican, Tennessee), a medical doctor who chairs the subcommittee on public health and safety of the Senate Labor and Human Resources Committee, and who is responsible for drafting a large "reauthorization" bill for the NIH.

The bill will set broad directions for NIH's work over several years. Frist wants to use the IOM study to explain to Congress how NIH reaches its decisions. In general he opposes attempts to direct NIH to spend specific sums on research on specific diseases.

Frist's aide Anne Phelps told the IOM panel that "the whole impetus for the study"

\section{Australia reviews medical research funding}

[SYDNEY] The Australian government has responded to intense lobbying against a large cut in funds for medical research, forecast in the May 1997 budget, by setting up the country's first 'strategic' review of health and medical research in 20 years.

The health minister, Michael Wooldridge, last week appointed 13 leading researchers, including three international experts, to an independent panel charged with identifying likely future developments, advising on how "to ensure a continuing research capacity in Australia matched to need" and developing an economic framework to achieve this.

Wooldridge says "there is no magic pudding" for

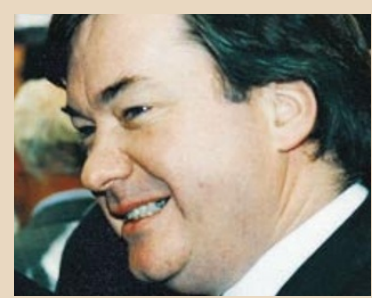

Woolridge: no magic, just a review.

research money, but that he was motivated "to take stock" by worries about career prospects for young researchers and the "major squeeze" on medical research.

The panel is chaired by Peter Wills, a businessman who also chairs the Garvan Institute of Medical Research in Sydney. The panel has a budget of $A \$ 1$ million (US $\$ 670,000)$ and will report by the end of the year. Wills aims "to demonstrate that money put into research is an investment, through, for example, developing better preventive techniques to defray health-care costs".

Peter Doherty, an Australian expatriate and a 1996 Nobel prizewinner, played a key role in the lobbying. Speaking from Memphis, Tennessee, he welcomed the latest move as "putting the subject clearly on the political agenda". Contrasting Australia's approach with recent US funding increases, he says: "The Australian national effort is, at best, in a holding pattern. Basic research and infrastructure are underfunded." Peter Pockley is to have a "process in place" against which to examine proposals for specific disease spending by members of Congress "other than debate on the Senate floor".

Phelps added that, with broad congressional support for doubling the NIH budget over five to ten years, Frist is feeling pressure from disease advocacy groups and their congressional supporters. She expressed a worry that members of Congress will pick five or six areas of research emphasis in the reauthorization bill. "We are very concerned about what will be missing."

There was praise for Harold Varmus, the NIH director, from Adam Yarmolinsky, a panel member who is a professor of public policy at the University of Maryland. He told Varmus at the meeting that he was doing a "superior" job of prioritizing.

Yarmolinsky suggested that NIH does not need the panel's "ideas about how to prioritize better," but rather its advice on how to justify the agency's decisions to the public.

Varmus asked the panel to consider whether there should be ways to make "more radical changes", having effects as big as fusing institutes or halving institutes' budgets. Although such drastic measures are "impossible politically", he said, the panel could consider other ways of achieving change if it did not think the changes NIH makes from year to year are "big enough".

On the issue of NIH responsiveness to the public, Varmus said he has learned "a lot" from highly educated disease advocacy groups. But he added: "There is a point beyond which the decision has to be reserved" for agency officials.

The institute directors who addressed the panel rallied around the current $\mathrm{NIH}$ process. Priority setting "is a complicated process, but you want it to be," said Francis Collins, director of the National Human Genome Research Institute. He likened any dramatically simpler scheme to landing a 747 aeroplane with a "joystick".

The directors warned against Congress earmarking research funds. Steven Hyman, director of the National Institute of Mental Health, said that a congressional requirement to devote 15 per cent of research spending to health services research, "lost [us] a substantial percentage of our basic neuroscience portfolio. People simply went away." Earmarking "entrenches self-interested constituencies" and "deforms" science, Hyman added.

But all the directors conceded an important role for public input into the NIH process. John Alderete, a panel member who is a professor of microbiology at the University of Texas Health Science Center at San Antonio, said NIH needs to be more responsive to the public if it wishes to avoid earmarking of funds.

MeredithWadman 